\title{
Air pollution in Kurdistan Region of Iraq: A review
}

\author{
Zanist Hama-Aziz ${ }^{1 *}$ \\ ${ }^{1}$ Charmo University, 46023 Chamchamal-Sulaimani, Kurdistan Regional, Iraq \\ Corresponding Author: zanist.hamaaziz@charmouniversity.org \\ Article history

Received $\quad$ Received in revised form Accepted Available online

30 July $2021 \quad$ 24 January 2022 24 February $2022 \quad 25$ February 2022

\begin{abstract}
Air pollution is an increasing environmental problem worldwide. People from Iraq and the Kurdistan Region of Iraq (KRI) constantly complain of poor air quality in the region. Many studies have investigated particular aspects of air pollution in the KRI, the issue, however, has never been comprehensively discussed. This study, unlike its precedents, collects all the documents, research articles, and ground facts available concerning air pollution, and aims to thoroughly understand all dimensions of the issue and classify its significant factors and sources. The result revealed that, compared to 40 years ago, current air quality in the KRI, specifically in the two largest cities of Erbil and Sulaimani, has deteriorated. The root causes were found to be political instability and wars in the region, a sharp increase in population, and poor public services. Similar to many other cities in developing countries, sources such as transportation have contributed in pollution. In addition, other significant sources such as dust storms, large and private power generators as well as household kerosene heaters which might not be present in other countries were found contributing in the escalation of the pollution. It is concluded that air pollution in the KRI is the outcome of a variety of causes and sources some of which may not be common in other parts of the world.

Keywords: air pollution, dust storms, Kurdistan Region of Iraq, kerosene heaters, private power generators, transportation
\end{abstract}

\section{Introduction}

To date, air pollution, both outdoor and indoor, is the biggest environmental risk to health, especially in developing countries. Being exposed to air pollution can cause health risks including difficulty in breathing, wheezing, coughing, asthma, worsening of existing respiratory and cardiac conditions, and death. According to the World Health Organization WHO [1], an estimated 7 million people die every year from exposure to polluted air; about half of these deaths are a result of breathing indoor air pollutants. Most of these deaths occur in Asia. Iraq, like the other developing countries, faces this problem too [2-4]. For example, Iraq, according to WHO [5] report, experienced an annual $\mathrm{PM}_{2.5}$ concentration at 50 $\mu \mathrm{g} / \mathrm{m}^{3}$ which is far above the standard line of 10 $\mu \mathrm{g} / \mathrm{m}^{3}$. It is well-known that particulate matter (PM) is the most common air pollutant that has severe short term and long term impacts on human health
Kurdistan Region of Iraq (KRI) where this study mainly focused is an autonomous region in the north of the country with approximately 7.2 million citizens (Figure 1). Generally, air quality in the KRI is better than that in the rest of Iraq because the KRI has more vegetation cover and more rainfall. However, residents in the KRI regularly complain about air quality deterioration. Therefore, researchers have carried out several investigations on particular aspects and sources of air pollution in the KRI. Nevertheless, none of those studies has addressed all of the issues concerning air pollution or presented the whole picture. Thus, the objective of this study is to collect all documents and research articles concerning air pollution in the KRI and classify the main causes and sources. The article is structured in the form that the main causes are presented followed by the main sources. At the end of the article, some suggestions are offered to improve air quality in KRI. This may help the rest of Iraq and other countries too, where air quality has been affected by the same factors of pollution. 


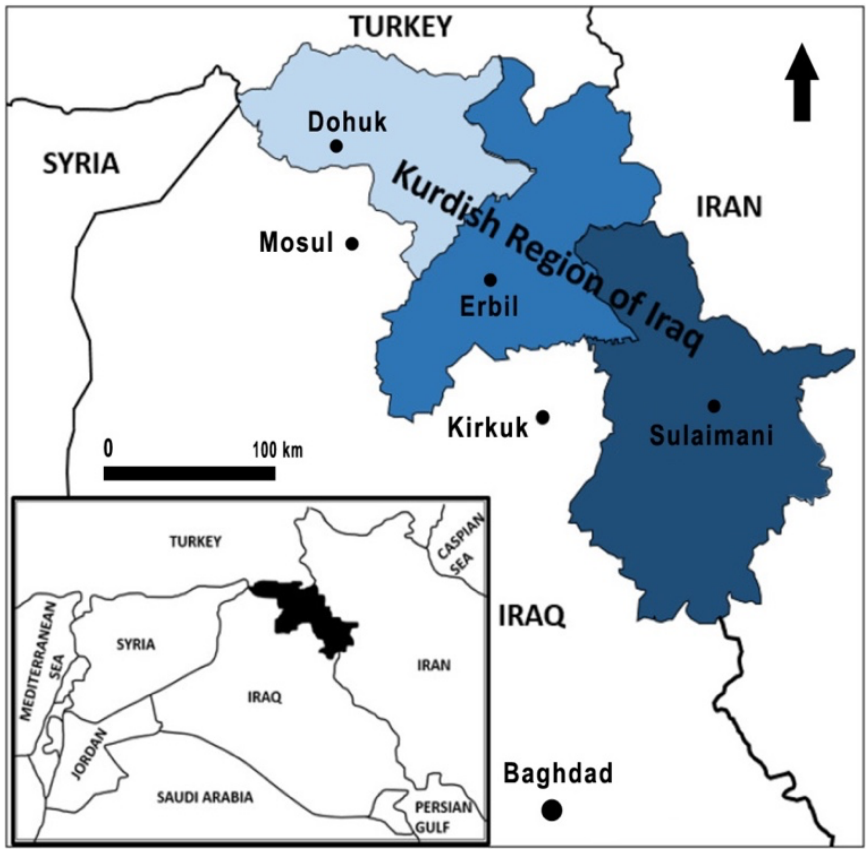

Figure 1 Map of the study area. This study focuses on the three major cities: Erbil, Sulaimani, and Dohuk in the Kurdistan Region of Iraq (KRI) in the northeastern part of Iraq

\section{Methods}

The information used in this article has been derived from multiple sources, such as research articles published in the international or the local journals, books, reports of the United Nations (UN) organizations and other international organizations, government documents, unpublished doctoral theses, personal communications with owners of several private power generators and with the union representative of private power generators in Sulaimani, in addition to articles from news websites. As an insider living and working in the KRI, the author's knowledge of the problem is also employed.

\section{Results and Discussion}

\subsection{Root causes of air pollution}

\subsubsection{Wars and sanctions}

It is broadly believed that some of the pollution the KRI experiences nowadays is linked to particular significant events that have happened in the last 40 years; thus, it is worth highlighting these causes. Before that, the country was fairly in peace and the government was able to provide public services to the inhabitants to a certain extent. The first major change happened in 1980 when the 8-year long Iraq- Iran war occurred, which costs $\$ 452$ billion [6]. The infrastructure of the areas now known as KRI was again hit badly by the Anfal campaign in 1988 when over 10,00 Kurdish villages were destroyed [7].

During the 1990s and after the First Gulf War in 1991, the second major change happened in the country, which was the international economic sanctions imposed by the UN Security Council on Iraq and Saddam Hussein's embargo on the KRI. Thus, the KRI at that time was under two economic sanctions. These sanctions lasted 11 years and paralyzed the country and its economy because of their comprehensive nature and extended duration. The sanctions prevented the reconstruction of the country which was completely devastated by the Gulf War damaging the country's infrastructure with losses estimated at $\$ 170$ billion $[8,9]$. The situation in the KRI in the 1990s was even worse than the rest of the country because of the double sanctions. According to a study by Kirk and Sawdon [10], $60 \%$ of the population in the KRI lived in deep poverty. The report concludes that the sanctions destroyed normal economic life for the vast majority. This all emphasizes that war and economic instability tend to be one of the reasons for the country's ruined infrastructure which, in turn, is responsible for much of the pollution in the country. If only a tiny portion of this massive cost had been spent on the improvement of urban infrastructure, the current urban environmental problems of all cities in Iraq could have been solved [11].

\subsubsection{The Sharp increase in population}

In 2003, a new era started in Iraq and the KRI when the Ba'ath regime was removed from the power. KRI then witnessed social peace, political stability, and economic prosperity. During this time, a sharp increase in population, rapid and unplanned urban expansion, and corruption are believed to be the root causes of air pollution in the KRI.

A great number of environmental scientists such as [12-14] indicate that increase in population is a major cause of pollution as has been formulated into a common pollution equation ( $\mathrm{I}=\mathrm{PAT})$, where $\mathrm{I}$ is impact or pollution, $\mathrm{P}$ is population, $\mathrm{A}$ is affluence, and $\mathrm{T}$ is technology. The population of the KRI has more than doubled in the last two decades, rising from 
3 million in 1997 to approximately 7.2 in 2019 [15, 16] which makes the KRI population intensity (177 people $/ \mathrm{km}^{2}$ ) more than twice that of the population intensity in the rest of Iraq $\left(83\right.$ people $\left./ \mathrm{km}^{2}\right)$. These figures are also found to be higher than those of the neighboring countries. Iran's population, for instance, increased in the last two decades by approximately $25 \%$, from 65.9 million to 82.1 million, and its population density in 2020 is 52 people $/ \mathrm{km}^{2}$ [17]. Similarly, Turkey's population rose by $25 \%$ from 66.4 million to 83.1 with a population density of 110 people $/ \mathrm{km}^{2}$.

This recent increase in population is attributed to the natural migration from rural to urban centers, forced migration, and international immigration. As discussed earlier, the Kurdish villages were all destroyed during the Anfal campaign and the villagers were either massacred or relocated to some concentration camps. And, possibly most importantly, the conflicts inside and outside Iraq including the USled occupation in 2003, the Iraqi civil war afterward, the Syrian civil war since 2011, and the Islamic State of Iraq and Sham's (ISIS) invasion of Mosul and the surrounding territories in 2014, all forced approximately 1.5 million Iraqis and non-Iraqis to leave the war zones and resettle in the KRI, where one in every four persons is either a refugee or an internally displaced person [18]. For example, over 250,000 Syrian refugees now live in the KRI which is about $99 \%$ of all Syrian refugees in Iraq [19]. Adding these people to the population of the KRI which has relatively poor infrastructures and poor economic conditions can only increase the burden on the economy, society, and environment. And lastly, the current stability in the region is attracting businesses, creating jobs, and stimulating international immigration into the cities (especially in the capital city-Erbil), so that ex-pats from different parts of the world now work there. This is also noted by Hassan [11] as he stated that the rise in population has been increasingly worsening the environmental problems in the KRI through consuming utilities, food, and water, using urban transport, and generating more waste.

\subsubsection{Poor public services}

Iraq was marked as the world's $18^{\text {th }}$ most corrupted country [20]. Corruption in the KRI is much talked about, yet far less documented. Illegal oil refineries are an apt example of corruption causing environmental problems, including deterioration of air quality, as they are not controlled by the government at all. Illegal oil refineries are common in the KRI, especially on the outskirts of Erbil. According to Lynch [21] and Ali [22], there are nearly 200 illegal oil refineries in Erbil that operate largely unregulated by safety or the environmental standards required by law, but only 50 of them are now closed because they are owned by influential people with ties to those in power. In addition, the KRI has very poor public transportation, possibly due to the wars and embargos mentioned earlier. Other studies such as [23, 24] have also shown that corruption has a negative and direct effect on air pollution. Furthermore, as the region does not provide 24 hours a day of electricity, people are forced to use kerosene heaters as well as large private power generators, and these are two sources of air pollution, as will be discussed later on in this article. If some portions of capital had been allocated for constructing power plants, there would not be air pollution from such sources.

Another issue of air pollution associated with poor public services is the lack of modern sanitary landfills where solid wastes are properly buried and tightly sealed. In nearly all towns and cities in the KRI, there are open dumpsites where tons of all types of solid waste is dumped on daily basis, and burned on some occasions, causing deterioration of air quality in the area. The two dominant dumping sites are Tanjaro in Sulaimani and Kani Qirzhala in Erbil. Majid [2] measured several air pollutants in 17 locations inside Sulaimani, including heavily trafficked streets, some parks, and residential areas, in the Tanjaro dumping site, and inside an unventilated tunnel. He observed that the Tanjaro dumping site has the highest $\mathrm{PM}_{2.5}$ value which was $178 \mu \mathrm{g} / \mathrm{m}^{3}$, which is over 17 times higher than the annual average (10 $\mu \mathrm{g} / \mathrm{m}^{3}$ ) set by the WHO [5]. As a result, it can easily be seen from the surrounding mountains in Sulaimani that the air quality in the south and southeast of the city, where the Tanjaro landfill is located, is poorer than that in the north.

\subsection{Major sources of air pollution}

\subsubsection{Transportation}

Transportation has always been a contributor to air pollution worldwide. Incomplete combustion in transportation releases several pollutants, such as carbon monoxide, soot, particulate matter, oxides of sulfur, oxides of nitrogen, ash, and lead. These 
primary pollutants react in the atmosphere to form ozone, secondary particulates, and carbon dioxide. There are few studies on air pollution in the KRI. In a comprehensive study of 7 measurements in 17 locations inside the city of Sulaimani including heavily trafficked streets and in some parks, Majid [2] found that $\mathrm{CO}, \mathrm{NO}_{2}, \mathrm{O}_{3}$ in all sampling sites were below the permissible limits set by the United States Environmental Protection Agency [25] and the European Commission [26]. However, he discovered that other pollutants including $\mathrm{PM}_{1}, \mathrm{PM}_{2.5}, \mathrm{PM}_{10}, \mathrm{SO}_{2}$, and $\mathrm{CO}_{2}$ in most of those locations exceeded the permissible limits of air quality. The author believes that the sources of high PM are both natural and anthropogenic, including transportation and dust storms.

Ahmed, et al. [27] measured Polycyclic Aromatic Hydrocarbon (PAHs) and Oxygenated (OPAHs) in $\mathrm{PM}_{10}$ in the air at the five most crowded streets in the downtown area of Sulaimani, and found that the average level of the carcinogenic $\mathrm{PAH} \mathrm{B}[a] \mathrm{P}$ was higher than the legislated EU target value by a factor of three. The average level of this compound was even higher than previous reports from Porto, Portugal; Beijing, China; Mazar-e Sharifin, Afghanistan; Stockholm, Sweden, and Rome, Italy. However, the concentrations of most of OPAH in Sulaimani were found to be lower than in most of the above-mentioned cities. The lowest PAH concentrations were determined during the nighttime when there is less traffic. This study also marked gasoline and diesel combustion as potential primary emission source of the PAH and OPAHs in the air PM of Sulaimani. Ostro [28] reported that in urban areas, mobile sources such as cars, trucks, and buses could contribute to more than $50 \%$ of PM pollution. AlArkawazi [29] too believes that up to $90 \%$ of air pollution in the rapidly growing cities in developing countries can be due to vehicles exhaust emissions.

The economic boom and rapid rise of the population in the KRI in the last two decades has resulted in a dramatic increase in the number of cars on the roads; this, in turn, contributed to air pollution in the region. The total number of vehicles (of all types) in the KRI in early 2020 is approximately $1,800,000$, equivalent to one vehicle for four persons, and these use around 7 million liters of fuel daily. Most of these vehicles are present in the largest three cities; Erbil alone has about 900,000 vehicles (approximately $50 \%$ of all cars in the KRI). The number of newly registered vehicles between 2016 and 2017 increased by $6.6 \%$, whereas this ratio is $3 \%$ and $5 \%$ for the USA and Turkey, respectively [16]. One of the obvious consequences of deteriorating air quality in the region is the presence of photochemical smog which is a mixture of primary and secondary pollutants formed under the influence of sunlight in cities with heavy traffic [12]. Most modern cities in the world have some photochemical smog, but it is much more common in cities with a dry, warm, sunny, mountainous climate with a large number of vehicles. The city of Sulaimani, unfortunately, has exactly these conditions and so, photochemical smog can be easily seen from its surrounding mountains.

It is not only the number of vehicles, but the system of transport in the KRI which is greatly different from the global and standard transportation system could be responsible for such deterioration in the air quality in the region. A large number of studies, such as [30-32], have determined the importance of public transportation in reducing urban air pollution. The public transportation system in the KRI, nevertheless, is very poor. Metro, train, or scheduled bus services do not exist. Only few private bus services are operating based upon the number of the passengers available rather than scheduled timetables, consequently, they are not found reliable and less used by the public. Most people have own vehicles and use them for their daily activities including regular commuting. Furthermore, KRI has been importing and exporting a large number of goods into and out of the region for the two decades of economic prosperity, but all of these goods are transported by road because the KRI is a landlocked region without a rail system. This has increased using trucks, both inside of and surrounding, the cities. KRI, further, exports about 500,000 barrels of oil per day through the Turkish port of Ceyhan [33]. The majority of oil fields, particularly in Sulaimani are not connected by pipelines; thus, the oil is transported by tanker trucks which, again, increases truck trips on the roads.

\subsubsection{Dust storm}

A dust or sand storm is a meteorological phenomenon common in arid and semi-arid regions. These can cause several environmental problems such as reducing visibility, generating clouds which in turn increase surface heat, damage the fertile topsoil, increase desertification, drought, reducing water 
supplies, and polluting the air. About concerning human health, it is well known that dust storms can carry such pathogens as bacteria, fungi, viruses, and heavy metals that can cause cardiovascular and respiratory diseases like a congestive cardiovascular failure, coronary artery disease, asthma or chronic obstructive pulmonary disease, and can, in some cases, lead to death $[34,35]$.

There are some studies on dust storms in Iraq and it is common knowledge that Iraq is, unfortunately, a country that experiences dust storms. The dust storms in Iraq now occur more frequently than in previous years, with a higher intensity than they did 30 years ago. As an example, between 1950 and 1990, the maximum length of the annual dust storm in Iraq was about 24 days. Contrast this with the record from 2008 when122 dust storms were recorded, and it is expected that Iraq could witness 300 dust storms per year in the next ten years [36]. KRI is located in a zone of low to moderate potential for dust storms, whereas the rest of Iraq is located in the zone of moderate to very high [37]. Between 1950-1990, KRI had significantly fewer days of dust storms (less than 4 days) per year compared to the rest of the country, but Majid [2] reported that between 2009-2010 Sulaimani has as many as 20 days of dust storms per year. Another study by Al-Kubaisi and Gardi [38] on dust storms in Erbil also noted a gradual increase in dust storms from 35 in 1992 to 65 in 2009. All of this indicates that dust storms in both Iraq and the KRI have increased significantly in number and severity as compared to those occurring in the last century.

The dust storms in both Iraq and KRI can be either regional or local. In the case of the former, a much larger area is affected and more severe health effects are felt than with the latter. Each type of that storm has its causes. The main causes behind the development of the regional dust storms are the climatic changes in the region (especially the remarkable decrease in the annual rate of rainfall), the significant increase in mean annual temperatures, and the notable increase of mean annual evaporation, besides environmental changes, such as dried marshlands, land degradation, and desertification. The causes for local dust storms are often down to military actions, construction operations, deforestation, cultivation, and unpaved roads [3].
It is interesting to note that all limited studies about dust storms in Iraq suggest that the first and most important cause of increasing dust storms over time is the drastic decline in annual precipitation [3, $38,39]$. The amount of rainfall in Iraq varies from the south and southwest parts $(100$ to $300 \mathrm{~mm}$ precipitation) toward the north and northeast parts (300 to $800 \mathrm{~mm}$ precipitation). Thus, KRI on the northeast receives a higher amount of precipitation (300 to $800 \mathrm{~mm}$ ) than the rest of Iraq, which explains why dust storms occur less often in the KRI than in the rest of the country. Al-Dabbas, et al. [39] reported that the average annual rainfall in Baghdad decreased from $138 \mathrm{~mm}$ for the years $1970-1979$ to about 36 $\mathrm{mm}$ for the years 2000-2008. And as concerns precipitation rates in the future for the KRI, a model study also found a significant downward trend in precipitation between 1961-2099 [40]. This expectation of a future reduction in precipitation in Iraq is also supported by the USAID [41], believing there will be a decrease in the mean annual rainfall by $9 \%$ by 2050 , with the greatest reduction $(-17 \%)$ expected during winter months. The effect of lack of precipitation in a developing dust storm was also highlighted by Hussain [42] when he noticed that the frequency of dust storms in Iraq was significantly higher in summer than in winter. The surface, therefore, loses its vegetation cover, contributing to the loosening of the topsoil cover, and contributing to the development of particles of clay and sand size. These particles were in action while the wind was blowing, causing a dust storm to develop.

Another major cause of increasing dust storms is rising temperatures. Al-Dabbas, et al. [39] reported that the average annual temperature in Baghdad rose from $21.9^{\circ} \mathrm{C}$ in 1971 to $23.6^{\circ} \mathrm{C}$ in 2008 , indicating a $1.7^{\circ} \mathrm{C}$ rises within 40 years. Similarly, Al-Kubaisi and Gardi [38] observed that the average annual temperature in Erbil rose from $20.7^{\circ} \mathrm{C}$ in 1992 to $22.7^{\circ} \mathrm{C}$ in 2009 , meaning a $2^{\circ} \mathrm{C}$ rises within just 17 years. As well, in a model study by Ibrahim [43], it was found that the highest land surface temperature for barren lands and build-up areas in Dohuk increased from $47^{\circ} \mathrm{C}$ in 1990 to $56^{\circ} \mathrm{C}$ in 2016 . The temperature in Iraq including the KRI is expected to rise $2^{\circ} \mathrm{C}$ more by 2050 [41] and will contribute to a higher evaporation rate, drought, salinization, desertification, and agricultural land degradation which, in turn, will increase the prevalence of dust storms. 


\subsubsection{Large \& private power generators}

As previously stated above, there is no 24 hour a day electricity service in the KRI. The government currently generates 3,500 megawatts of electricity, which provides eight hours of electricity for each household in the region. 6,000 megawatts must be produced to provide electricity for 24 hours. This lack of available power has primarily arisen because the power generation infrastructure in both the KRI and Iraq was ruined during the two decades of war and sanctions. People, therefore, had used small, portable power generators placed at homes which, since 2007, were substituted by large, stationary diesel power generators placed in neighborhoods. These generators start operating when public electricity is not supplied, and the power is shared amongst 100-200 subscribed households. Increased demand for power and the low generation capacity of the country has led to an increase in the number of these generators and their operating times. In total, there are approximately 5,000 large diesel generators in the KRI. Inside Sulaimani city alone, for instance, 455 diesel generators were producing about 160 megawatts of electricity in 2010 [2]; however, according to T. Samin, the representative of the Union of private generators in Sulaimani (personal communication, November 20, 2019), the number of the generators rose significantly to about 680 in 2019 producing approximately 400 megawatts of power. An average of 15 hours of electricity was provided daily by these generators in 2018. Therefore, it is estimated that 750,000 liters of diesel fuel are combusted daily by these generators in Sulaimani city considering that 70-80 liters of diesel are needed to provide one-hour electricity.

These power generators are considered to be significant contributors to deteriorating air quality in the KRI as they are releasing numerous hazardous air contaminants and greenhouse gases including particulate matter, carbon monoxide, carbon dioxide, and oxides of nitrogen. If a general rule, such as the consumption of one liter of diesel emitting around $2.7 \mathrm{~kg}$ of $\mathrm{CO}_{2}$ [44] is considered, then the 750,000 liters of diesel will release about 2,000 tons of $\mathrm{CO}_{2}$ /day in Sulaimani city. The 750,000 liters is approximately equivalent to the quarter of the total fuel combusted by all types of transportation in Sulaimani city. Furthermore, the power generations are all placed inside cities, not in their surroundings, and they combust dirtier fuel (diesel) rather than gasoline. All of this means that the power generators could be as serious as transportation with air pollution in the KRI. Moreover, during a few personal communications, some owners of these generators complained about the high sulfur content in the diesel fuel usually provided by the local authorities or the merchants. Owners of the generators noted that exhausts of the generators became corroded after operating for a few years which possibly supports the argument that the diesel fuel used for these generators contains high sulfur. Although there is no scientific study on the impact of such generators on the air quality inside KRI, Saiyasitpanich, et al. [45] found that the increase of sulfur content in the diesel fuel is strongly correlated with the increase of diesel particulate matter.

Another significant environmental issue with these generators is their location. They are placed in neighborhoods to minimize the loss of power to the subscribed households. Although they are instructed by the local authority to place them far away from the community and to plant trees around them, owners usually disregard the regulations. Thus, most generators are located next to the houses. In addition to the polluted air released into the area, noise is another matter of concern. The sound level of $100 \mathrm{~dB}$ was measured at 1-meter distance from a generator. Mahammed, et al. [46] studied the noise level from 30 generators in Dohuk and found that the average noise level at $50 \mathrm{~m}$ distance from the generators was $74 \mathrm{~dB}$ which was higher than the permissible noise level of $(55 \mathrm{~dB}$ and $65 \mathrm{~dB})$ for residential and commercial areas, respectively. The measured value $(74 \mathrm{~dB})$ was near the permissible noise level of $(75 \mathrm{~dB})$ for industrial areas, meaning that the noise level in residential areas in some cities in the KRI is as high as industrial areas.

In response to a large number of complaints from people about environmental problems associated with the generators; local authorities are now tightening the regulations by implementing some measures. Most of the generators now in Sulaimani are silent generators, and the Erbil governor has recently decided to replace all ordinary generators with silent generators by mid-2020. The generators now have to be annually inspected by governmental officials. Furthermore, owners of the generators have to plant 25 trees annually to be able to renew their licenses. In an initiative, 10,000 trees were planted by 
the owners of the generators in Sulaimani in 2019 to compensate for air pollution caused by the generators.

\subsubsection{Kerosene Heaters}

As mentioned earlier, indoor air pollution is as serious a problem as outdoor air pollution is, causing the death of about 3 million people per annum worldwide since people spend at least $70 \%$ of their time indoors [1]. Indoor air pollution includes a wide variety of sources such as kerosene heaters, gas heaters, wood stoves, tobacco smoke, air fresheners, dry cleaning fluid fumes, carpets, paint strippers, and thinners. Kerosene heaters have been used to warm the indoors during the winter in many countries in the past century; however, they are seldom used now as they have been replaced with modern devices using main electricity. But in the Kurdistan Region, 24-hour electricity is not available. Winter is extremely cold (sometimes falling below $-10 \mathrm{C}$ ), therefore, there is a great demand for electricity and the government can only provide a maximum of 8 hours per day at peak time. Aside from electric heaters and radiators, people use several other types of appliances to warm the indoors including kerosene heaters, gas heaters, and wood-burning stoves. Of these, kerosene heaters have been the most used in the last century in the KRI and they remain the most common appliance used for heating during winter. A possible reason for this could be due to the subsidization of 200 liters of kerosene per family by the government each year.

From its early introduction, especially during the 1980 s, extensive studies conducted globally were carried out to determine the effect of the kerosene heaters on indoor air pollution and their effect on human health. Tu and Hinchliffe [47] studied the emissions from 3 conventional electrical heaters, 1 quartz electrical heater, and 1 kerosene heater. Their results indicated that the aerosol concentration in an unvented chamber can be as high as $330 \mu \mathrm{g} / \mathrm{m}^{3}$ from a kerosene heater used for $1 \mathrm{~h}$. The kerosene heater released 1 to 2 orders of magnitude more particles, both in mass and number than the other heaters. Similarly, in a comparative study, Ruiz, et al. [48] found that emissions inside homes using kerosene heaters were significantly higher than the emissions inside homes using electrical devices and/or central heating. Traynor, et al. [49] found that kerosene heaters can emit (PAHs); nitrated PAHs; alkylbenzenes, phthalates; hydronaphthalenes; aliphatic hydrocarbons, alcohols, ketones; and other organic compounds, some of which are known mutagens. Other studies such as [50-52] found kerosene heaters to be a significant source of $\mathrm{CO}_{2}$, $\mathrm{CO}, \mathrm{NO}_{\mathrm{x}}$, and $\mathrm{SO}_{2}$. Exposure to emissions from kerosene heaters can cause headaches, dizziness, pain and tighten in the chest, blurred vision, nausea, and even death. Some demographic groups such as pregnant women, asthmatics, people with heart and lung diseases, children, and the elderly may be more adversely affected by these gases than the general public.

Although kerosene heaters have been widely used in the KRI, there is no scientific study thus far has been done on the health issues of their users. Anecdotally, however, it is known generally that many people complain about headaches, dizziness, and fatigue after using kerosene heaters, particularly at the beginning of the cold season. The low quality of kerosene used in the KRI can be one of the reasons for developing such health issues. Most of the kerosene heaters have to be placed outside of the homes during turning on and switching off to let the bad smell and polluted air release outdoors because the state of air quality on these occasions are intolerable. Also, there are many incidents of burns and deaths due to kerosene heaters that have been reported by the media and the police. It has been noted that most deaths occur at night when the kerosene heaters are left operating, unvented, and most burns and fire incidences happen during the day when people, especially children, are around the kerosene heaters. Nawzad [53] reported that in 2019 a fire caused by a kerosene heater killed four children in a tent of a refugee's camp outside Kirkuk. As well, Basnews English [54] reported that in 2019 three people from the same family died; their deaths were caused by the fire from a kerosene heater in the town of Akre in Dohuk province. Kerosene heaters are the dominant type of heater used in schools and occasionally fire accidents have occurred. Basnews English [55] stated that a fire incident at a school in central Erbil injured two teachers when one of the students hit a kerosene heater.

\section{Conclusions}

Air pollution is a serious environmental problem worldwide including in Iraq and the KRI. Several studies have highlighted different dimensions of such problems in the KRI; however, the entire issue has never been discussed comprehensively. This study 
gathered all documents, research articles, and ground truths regarding air pollution in the KRI and aimed to gain an extensive understanding of all aspects of the problem and classify significant causes and sources of air pollution in that region. Results showed that air pollution in the KRI is caused by three main factors, namely: a series of destructive wars in the region, a sharp increase in population, and poor public services. It is observed that the most significant sources were dust storms, household kerosene heaters, and large \& private power generators which are not common in other parts of the world. Transportation was also found to be a major source of air pollution in the KRI, and is considered to be a substantial contributor worldwide. Thus, it is concluded that most aspects of air pollution in the KRI were different from those of the other countries, making solutions and prevention difficult. Sources of air pollution such as regional dust storms could not be controlled by the people and the local authorities as they originate outside their borders. However, most other sources such as local dust storms, transportation, kerosene heaters, and generators can be tackled through a combination of several solutions. The first and the most important solution is public transportation. Investment can be made in providing intracity and intercity timescheduled buses as well as metros. The government should also capitalize on constructing more electric power plants to increase power supply, leading residents not to rely on other unsafe, polluting appliances such as diesel generators and kerosene heaters. Since this semi-arid region is expected to be drier and hotter in the future, the current greenery area $(12 \%)$ for the KRI [56] should be enlarged to decrease local dust storms, reduce water evaporation, cool the weather, and freshen the air. Furthermore, the KRI population intensity is more than twice that of the Iraqi population intensity, so the current sharp rise of the population should be controlled to some extent. Finally, more research is suggested to determine and quantify all factors associated with air pollution in the KRI.

Funding: Not applicable

Conflicts of interest: There is no conflict of interest

\section{References}

[1] WHO. "Key facts." https://www.who.int/newsroom/air-pollution (accessed Oct. 17, 2020)

[2] S. N. Majid, "Valuation of ambient air pollution: a study of some urban areas in Sulaimani City and its surrounding/Kurdistan region of Iraq," $\mathrm{PhD}$ thesis, Agriculture Sciences, University of Sulaimani, 2011.

[3] V. Sissakian, N. Al-Ansari, and S. Knutsson, "Sand and dust storm events in Iraq," Journal of Natural Science, vol. 5, no. 10, pp. 1084-1094, 2013.

[4] M. T. Chaichan, H. A. Kazem, and T. A. Abed, "Traffic and outdoor air pollution levels near highways in Baghdad, Iraq," Environment, development and sustainability, vol. 20, no. 2, pp. 589-603, 2018.

[5] WHO. "Ambient air pollution: A global assessment of exposure and burden of disease." (accessed Oct. 20, 2020

[6] A. Alnasrawi, "Economic devastation, underdevelopment, and outlook," in Iraq Since the Gulf War: Prospects for Democracy, F. Hazelton, Ed. London: Zed Books, 1994, pp. 72-69.

[7] M. Leezenberg, "The Anfal Operations in Iraqi Kurdistan," in Centuries of Genocide: Essays and Eyewitness Accounts, S. Totten and W. Parsons, Eds. 4th ed. New York: Routledge, 2013, pp. 359421.

[8] H. Ascensio and M. Dixneuf, "Sanctions Against Iraq and Human Rights:a devastating, misguided, intolerable method," International Federation for Human Rights, March 2002.

[9] R. Morran, R. Normand, J. Paul, J. Rempel, and C. Wilcke. "Iraq Sanctions: Humanitarian Implications and Options for the Future," in Global Policy Forum, Aug, 2002, vol. 6.

[10] A. Kirk and G. Sawdon, "Understanding Kurdish Livelihoods in Northern Iraq: Final Report," The Northern Iraq Country Programme and the Food Security and Livelihoods Unit, Save the Children, UK, London, 2002.

[11] M. K. R. Hassan, "Urban environmental problems in cities of the Kurdistan region in Iraq," Local Environment, vol. 15, no. 1, pp. 59-72, 2010.

[12] G. T. Miller and S. E. Spoolman, Environmental science, thirteenth ed. Lincoln: Brooks/Cole, Cengage Learning, 2010.

[13] J. H. Withgott, M. Laposata, and B. Murck, Environment: The Science Behind the Stories, Third Canadian ed. Toronto: Pearson, 2016.

[14] M. R. Chertow, "The IPAT equation and its variants," Journal of industrial ecology, vol. 4, no. 4, pp. 13-29, 2000.

[15] D. T. Menmy. "Iraqi population census raises concerns of Kurds." https://www.almonitor.com/pulse/originals/2019/09/iraq-censuskurdistan-baghdad.html (accessed Oct. 6, 2020)

[16] H. Mohammed, D. Jaff, and S. Schrock, "The challenges impeding traffic safety improvements in the Kurdistan Region of Iraq," Transportation 
Research Interdisciplinary Perspectives, p. 100029, 2019.

[17] Trading Economics. "Iran Population." https://tradingeconomics.com/iran/population (accessed Oct. 26, 2020)

[18] UNHCR. "Iraq emergency." https:/www.unhcr.org/iraq-emergency.html (accessed Nov. 11, 2020

[19] Durable Solutions Platform. "Far from home: future prospects for Syrian refugees in Iraq." https://reliefweb.int/report/iraq/far-home-futureprospects-syrian-refugees-iraq (accessed Oct. 16, 2020)

[20] Transparency International. "Corruption Perceptions Index 2019." https://www.transparency.org/cpi2019 (accessed Oct. 16,2020

[21] H. Lynch. "Kurdistan's illegal oil refineries devastate land and public health." https://www.rudaw.net/english/kurdistan/2309201 91 ( accessed Oct. 16, 2020)

[22] S. Ali. "Illegal oil refineries in Erbil threaten health, environment: Official." https:/www.kurdistan24.net/en/news/9c3b84adc32c-4baf-b9dc-b8ae5bdc9814 (accessed Oct. 16, 2020)

[23] S.-C. Chang and T.-y. Chang, "The relationships between corruption and pollution on corruption regimes," Economics Bulletin, vol. 30, no. 3, pp. 1942-1949, 2010.

[24] L. Pellegrini and R. Gerlagh, "Corruption, democracy, and environmental policy: an empirical contribution to the debate," The Journal of Environment \& Development, vol. 15, no. 3, pp. 332-354, 2006.

[25] United States Environmental Protection Agency. "National Ambient Air Quality Standards Table." https://www.epa.gov/criteria-air-pollutants/naaqstable (accessed Oct. 24, 2020)

[26] European Commission. "Air Quality Standards." https://ec.europa.eu/environment/air/quality/standa rds.htm_(accessed Oct. 24, 2020)

[27] T. M. Ahmed, B. Ahmed, B. K. Aziz, C. Bergvall, and R. Westerholm, "Native and oxygenated polycyclic aromatic hydrocarbons in ambient air particulate matter from the city of Sulaimaniyah in Iraq," Atmospheric Environment, vol. 116, pp. 4450, 2015.

[28] B. Ostro, "Outdoor air pollution: Assessing the environmental burden of disease at national and local levels," in "Environmental Burden of Disease, Series, No. 5.," World Health Organization, 2004.

[29] S. A. F. Al-Arkawazi, "Measuring the Influences and Impacts of Signalized Intersection Delay Reduction on the Fuel Consumption, Operation
Cost and Exhaust Emissions," Civil Engineering Journal, vol. 4, no. 3, pp. 552-571, 2018.

[30] X. Basagaña et al., "Effect of public transport strikes on air pollution levels in Barcelona (Spain)," Science of the total environment, vol. 610, pp. 1076-1082, 2018.

[31] D. Rojas-Rueda, A. De Nazelle, O. Teixidó, and M. Nieuwenhuijsen, "Replacing car trips by increasing bike and public transport in the greater Barcelona metropolitan area: a health impact assessment study," Environment international, vol. 49, pp. 100-109, 2012.

[32] R. J. Shapiro, K. A. Hassett, and F. S. Arnold, "Conserving energy and preserving the environment: The role of public transportation," American Public Transportation Association, 2002.

[33] W. Fairbanks, "Iraqi Kurdistan closes in on 500,000 B/D oil production,"MEES, vol. 62, no. 45, Nov. 2019

[34] A. Miri, H. Ahmadi, A. Ghanbari, and A. Moghaddamnia, "Dust storms impacts on air pollution and public health under hot and dry climate," International journal of energy and environment, vol. 2, no. 1, pp. 101-105, 2007.

[35] S. J. A. Ebrahimi, L. Ebrahimzadeh, A. Eslami, and F. Bidarpoor, "Effects of dust storm events on emergency admissions for cardiovascular and respiratory diseases in Sanandaj, Iran," Journal of Environmental Health Science and Engineering, vol. 12, no. 1, p. 110, 2014.

[36] M. Kobler. "Combating dust-storms: our responsibility to future generations." http://www.uniraq.com/index.php?option=com_k2 \&view=item\&id=403: combating-dust-storms-ourresponsibility-to-future-

generations\&Itemid $=606 \&$ lang $=$ en (accessed Oct. 21, 2020)

[37] Desert Research Institute. "Integrated desert terrain forecasting for military operations (DTF)." https://www.dri.edu/earth-ecosystemsciences/earth-eco-research/1782-integrateddesert-terrain-forecasting-for-military-operationsdod-desert-terrain ( accessed March 17, 2020)

[38] Q. Y. Al-Kubaisi and L. M. Gardi, "Dust storm in Erbil city as a result of climatic change in Kurdistan Region Iraq," Iraqi Journal of Science, vol. 53, no. Special Issue, pp. 40-44, 2012.

[39] M. A. Al-Dabbas, M. A. Abbas, and R. M. AlKhafaji, "Dust storms loads analyses-Iraq," Arabian Journal of Geosciences, vol. 5, no. 1, pp. 121-131, 2012.

[40] N. Al-Ansari, M. Abdellatif, M. Ezeelden, S. S. Ali, and S. Knutsson, "Climate change and future long term trends of rainfall at north-eastern part of Iraq," Journal of Civil Engineering and Architecture, vol. 8, no. 6, pp. 790-805, 2014. 
[41] USAID, "Climate Change Risk Profile: Iraq. Fact Sheet," USAID, Washington, D.C2017, Available: https://www.climatelinks.org/sites/default/files/ass et/document/2017Mar3_GEMS_Climate\%20Risk

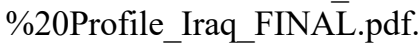

[42] A. I. Hussain, "The nature, source and composition of the dust storms in Tikrit/Iraq," Iraqi Journal of desert studies, vol. 4, no. 1, pp. 23-34, 2012.

[43] G. R. F. Ibrahim, "Urban land use land cover changes and their effect on land surface temperature: Case study using Dohuk City in the Kurdistan Region of Iraq," Climate, vol. 5, no. 1, p. 13, 2017.

[44] A. Q. Jakhrani, A. R. H. Rigit, A.-K. Othman, S. R. Samo, and S. A. Kamboh, "Estimation of carbon footprints from diesel generator emissions," in 2012 International Conference on Green and Ubiquitous Technology, 2012, pp. 7881: IEEE.

[45] P. Saiyasitpanich, M. Lu, T. C. Keener, F. Liang, and S.-J. Khang, "The effect of diesel fuel sulfur content on particulate matter emissions for a nonroad diesel generator," Journal of the Air \& Waste Management Association, vol. 55, no. 7, pp. 993-998, 2005.

[46] M. A. Mahammed, F. A. Kochery, and M. S. Abdulkhaliq, "Investigation of Noise Pollution of Electrical Diesel Generators in Duhok City/Kurdistan of Iraq," Science Journal of University of Zakho, vol. 1, no. 1, pp. 319-324, 2013.

[47] K. Tu and L. Hinchliffe, "A study of particulate emissions from portable space heaters," American Industrial Hygiene Association Journal, vol. 44, no. 11, pp. 857-862, 1983.

[48] P. A. Ruiz, C. Toro, J. Cáceres, G. Lopez, P. Oyola, and P. Koutrakis, "Effect of gas and kerosene space heaters on indoor air quality: a study in homes of Santiago, Chile," Journal of the Air \& Waste Management Association, vol. 60, no. 1, pp. 98-108, 2010.

[49] G. W. Traynor, M. G. Apte, H. A. Sokol, J. C. Chuang, W. G. Tucker, and J. L. Mumford, "Selected organic pollutant emissions from unvented kerosene space heaters," Environmental science \& technology, vol. 24, no. 8, pp. 12651270, 1990.

[50] B. P. Leaderer, P. M. Boone, and S. K. Hammond, "Total particle, sulfate, and acidic aerosol emissions from kerosine space heaters," Environmental Science \& Technology, vol. 24, no. 6, pp. 908-912, 1990.

[51] P. B. Ryan, J. D. Spengler, and R. Letz, "The effects of kerosene heaters on indoor pollutant concentrations: a monitoring and modeling study," Atmospheric Environment (1967), vol. 17, no. 7, pp. 1339-1345, 1983.
B. P. Leaderer et al., "Indoor, outdoor, and regional summer and winter concentrations of PM10, PM2. 5, $\mathrm{SO}_{4}{ }^{2-}, \mathrm{H}^{+}, \mathrm{NH}_{4}{ }^{+}, \mathrm{NO}_{3}{ }^{-}, \mathrm{NH}_{3}$, and nitrous acid in homes with and without kerosene space heaters," Environmental Health Perspectives, vol. 107, no. 3, pp. 223-231, 1999.

[53] K. Nawzad. "Tent fire at IDP camp in Kirkuk kills four children." https://www.kurdistan24.net/en/news/7715b9602291-4f0a-9967-3a1caedd0a1e (accessed Nov. 6, 2020)

[54] Basnews English. "Three Killed, One Injured in Akre Fire Incident." http://www.basnews.com/index.php/en/news/kurdi stan/504088 (accessed Nov. 6, 2020)

[55] Basnews English. "Two Teachers Slightly Injured in Erbil School Fire." http://www.basnews.com/index.php/en/news/kurdi stan/487634 (accessed Oct. 30, 2020)

[56] Z. Z. Wali. "Kurdish park rangers crack down on tree felling as winter approaches." https://www.rudaw.net/english/kurdistan/3110201 91 (accessed, Oct. 21, 2020) 